\title{
Aplikasi Tenaga Surya sebagai Sumber Energi Alternatif
}

\author{
Nur Hayati \\ Program Studi Teknik Mesin IST Akprind Yogyakarta \\ E-mail : nurhayati@akprind.ac.id
}

\begin{abstract}
Abstrak
Program pengabdian kepada masyarakat ini bertujuan untuk memanfaatkan tenaga matahari sebagai sumber energi listrik pengganti sumber listrik PLN di Bopongan RT 04 padukuhan Kauman, Tamanan, Banguntapan, Bantul. Adapun metode pelaksanaan abdimas ini dimulai dengan pendataan rumah warga yang belum dialiri arus listrik PLN kemudian dilakukan sosialisasi tentang teori panel surya kepada warga masyarakat dan diakhiri dengan pemasangan panel surya di rumah warga. Hasil abdimas cukup memuaskan yaitu warga yang belum memperoleh aliran listrik PLN dapat menikmati penerangan dengan sumber energi elternatif.
\end{abstract}

Kata kunci: tenaga matahari, listrik, penerangan

Abstract
This community service program aims to utilize solar power as a source of electrical energy to replace the PLN electricity source at Bopongan RT 04 Padukuhan Kauman, Tamanan, Banguntapan, Bantul. The method of implementing this abdimas begins with data collection of residents 'houses that have not yet been supplied with electricity from PLN, then socialization is carried out about the theory of solar panels to residents and ends with the installation of solar panels in residents' homes. The results of the Community Service were quite satisfying, namely residents who had not yet received PLN electricity were able to enjoy lighting with alternative energy sources.

Keywords:solar power, electricity, lighting

\section{PENDAHULUAN}

Listrik sudah menjadi kebutuhan utama pada jaman sekarang. Kebutuhan listrik sebagian besar disuplai oleh perusahaan listrik negara (PLN) tetapi belum semua wilayah di Indonesia mendapatkan jaringan listrik tersebut, sedangkan permintaan energi listrik setiap tahun terus meningkat. Berbagai upaya telah dilakukan oleh pemerintah atau masyarakat sendiri dengan membangun pembangkit secara mandiri dari berbagai macam sumber energi. Pembangkit alternatif terbarukan yang cocok dengan keadaan geografis adalah PLTS (Pembangkit Listrik Tenaga Surya). Sebagai negara tropis dengan kondisi sinar matahari yang terus bersinar sepanjang tahun di berbagai wilayah, menjadikan Indonesia memiliki potensi besar bagi pengembangan PLTS. Potensi energi surya di Indonesia rata-rata tercatat sebesar 4,8 $\mathrm{kWh} / \mathrm{m} 2$ atau setara $112.999 \mathrm{GWp}$. Meskipun memiliki potensi besar, namun yang baru dimanfaatkan hingga saat ini baru sekitar $16 \mathrm{MWp}(0,03 \%$ dari potensi) dengan total produksi sebesar 21,09 GWh. Untuk propinsi Di Yogyakarta sendiri memiliki potensi teoritis sebesar 6,892 MW [1]

Pemanfaatan energi terbarukan diantaranya dengan memanfaatkan tenaga radiasi matahari menggunakan sel surya sebagai pengkonversi energi matahari menjadi energi listrik yang kita kenal dengan Pembangkit Listrik Tenaga Surya (PLTS). Cahaya matahari terdiri atas foton atau partikel energi surya yang dikonversi menjadi energi listrik. Energi yang diserap oleh sel surya diserahkan pada electron sel surya untuk dikonversi menjadi energi listrik [2] 
Unjuk kerja dari photovoltaic cell sangat tergantung kepada sinar matahari yang diterimanya. Kondisi iklim (misal awan dan kabut) mempunyai efek yang signifikan terhadap jumlah energi matahari yang diterima sel sehingga akan mempengaruhi pula unjuk kerjanya [3]

\section{METODE}

Kegiatan ini merupakan pengabdian kepada masyarakat yang diterapkan di wilayah padukuhan Kauman yang terletak di desa Tamanan, kecamatan Banguntapan, kabupaten Bantul, Yogyakarta karena ada sebagian wilayah belum teraliri listrik PLN. Masyarakat masih menggunakan lampu minyak sebagai sumber penerangan. Metodologi yang digunakan dalam pengabdian ini digambarkan dalam bentuk diagram alir (flowchart) yang sistematis seperti Gambar 1 berikut :

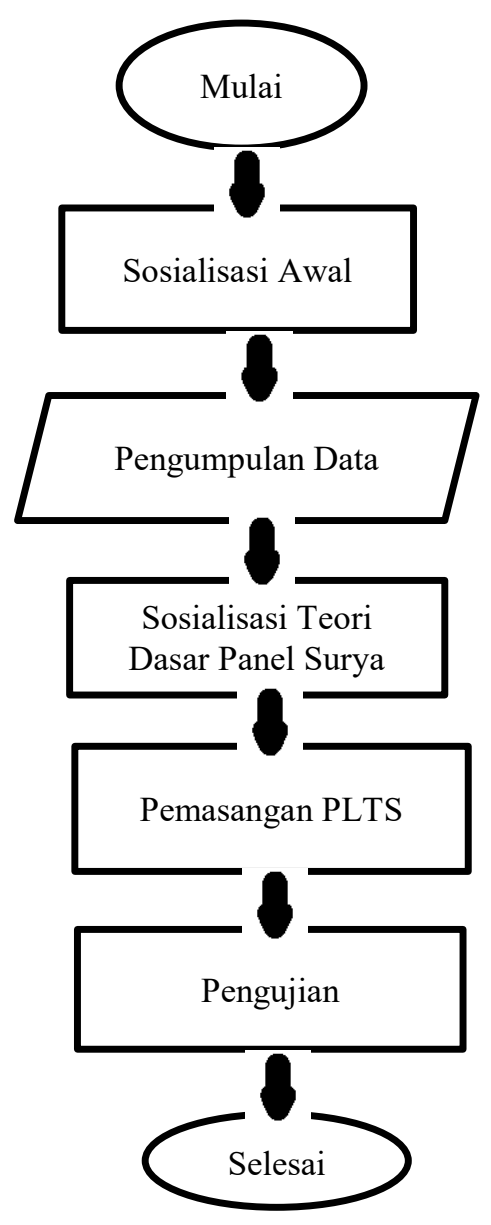

Gambar 1. Diagram alir pengabdian

Tahapan kegiatan pengabdian masyarakat ini dimulai dengan sosialisasi awal kepada warga bersama perangkat desa dengan mengunjungi rumah warga yang belum dialiri listrik PLN. Hal ini bertujuan untuk melakukan pendataan kebutuhan panel surya. Tahap selanjutnya adalah sosialisasi tentang teori-teori dasar mengenai panel surya, teknik pemasangan dan prosedur keselamatan yang berlaku. Kegiatan melibatkan karang taruna dan 
warga. Pada akhir kegiatan dilakukan pemasangan instalasi panel surya di rumah warga yang belum dialiri listrik PLN. Setelah dilakukan pemasangan panel surya, kemudian dilakukan pengujian dan selesai.

\section{HASIL DAN PEMBAHASAN}

Sebelum dilakukan pemasangan panel surya, dilakukan sosialisasi tentang teori-teori dasar mengenai panel surya, teknik pemasangan dan prosedur keselamatan yang berlaku. Kegiatan ini melibatkan karang taruna dan warga. Antusiasme warga terlihat dari banyaknya warga yang datang menghadiri pelatihan. Selain itu antusiasme warga juga terlihat dari keingintahuan warga terhadap panel surya. Berbagai pertanyaan diajukan terkait dengan panel surya sebagai sumber listrik alternatif. Berikut disajikan daftar hadir peserta sosialisasi.

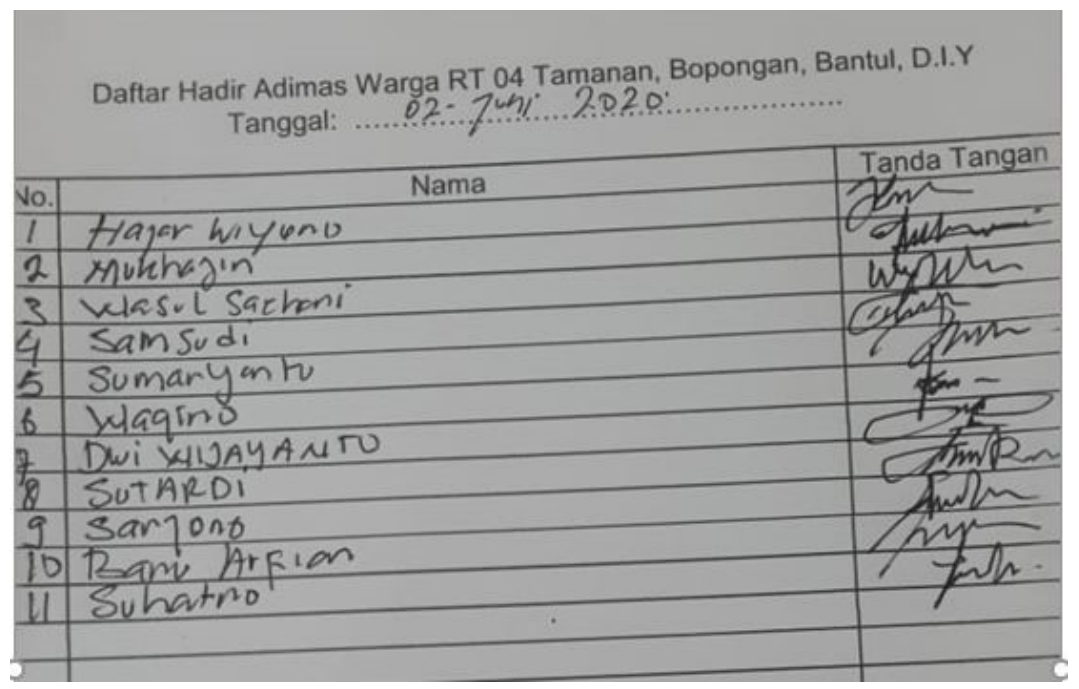

Gambar 2. Daftar hadir warga yang mengikuti kegiatan sosialisasi abdimas

Adapun instalasi panel surya harus dilakukan dengan memperhatikan keamanan pemasangan kabel. Instalasi dasar dari panel surya disajikan dalam gambar berikut :

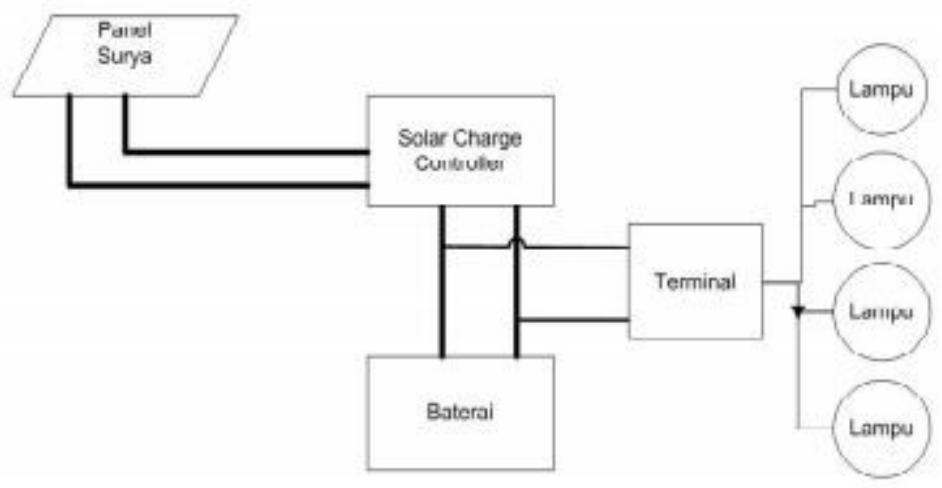

Gambar 3. Skema instalasi dasar panel surya [4]

Energi surya fotovoltaik digunakan untuk memenuhi kebutuhan listrik, pompa air, televisi, telekomunikasi, dan lemari pendingin di daerah yang belum terjangkau oleh aliran listrik PLN. Foton sinar matahari akan diubah menjadi arus listrik oleh sel-sel fotovoltaik. 
Arus listrik kemudian diarahkan menuju controller dan dipergunakan untuk mengisi arus baterai sebagai tenaga cadangan ketika energi matahari kurang mencukupi. Selain itu controller juga berfungsi agar tegangan yang dihasilkan menjadi stabil pada tegangan kerja yang diharuskan. Energi yang dihasilkan dapat langsung dipergunakan untuk menyalakan peralatan listrik yang membutuhkan arus searah atau DC. Untuk mengoperasikan peralatan listrik yang membutuhkan arus bolak-balik (DC) maka digunakan converter. Penggunaan panel surya adalah mahal dalam biaya instalasi awal tetapi murah bahkan dikatakan minim biaya dalam operasional [5]

Pemasangan panel surya terkendala hasil yang tidak maksimal, hal ini disebabkan peletakan sudut dari panel surya yang tidak tepat seperti diungkapkan bahwa daya yang dihasilkan sangat bergantung pada intensitas matahari yang diterima oleh panel surya. Intensitas radiasi matahari yang diterima oleh panel surya dapat dimaksimalkan dengan cara memasang panel surya, dengan sudut kemiringan atau slope dan sudut azimut yang tepat [6]. Selain itu panel tidak terhalang oleh bayangan di sekitar panel untuk memaksimalkan sinar matahari yang masuk.

Gambar berikut disajikan foto pemasangan panel surya di rumah warga dibantu oleh karang taruna setempat

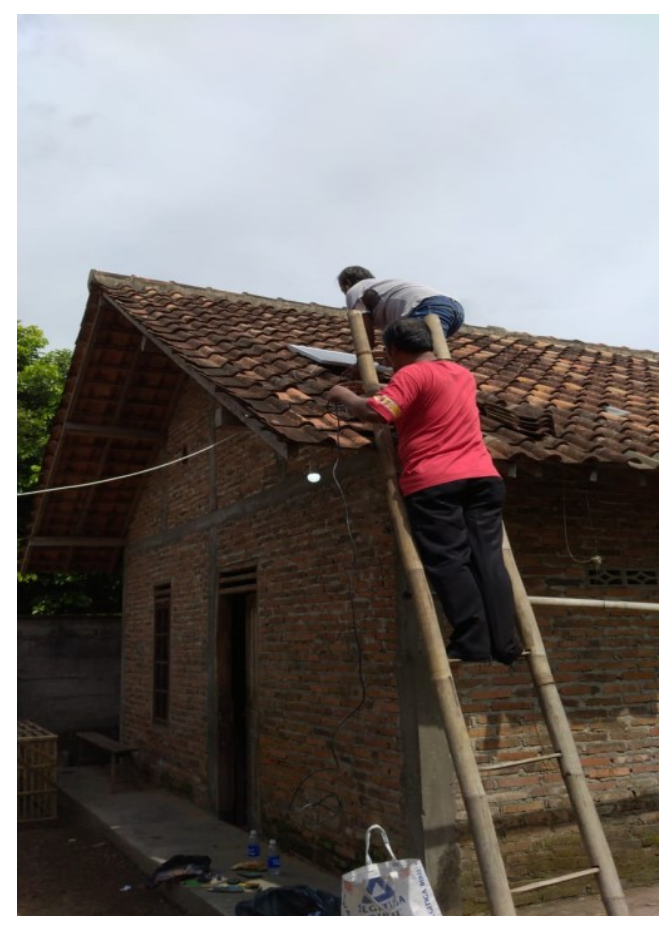

Gambar 4. Pemasangan panel surya dibantu karang taruna setempat

Setelah dilakukan pemasangan panel surya, warga yang belum dapat menikmati aliran listrik PLN sekarang dapat menikmati penerangan. Panel surya dapat digunakan sebagai sumber energi listrik alternatif. Selain itu penggunaan panel surya dapat mengurangi biaya operasional pemakaian listrik. Berikut disajikan gambar penerangan rumah dengan menggunakan sumber energi alternatif panel surya. 

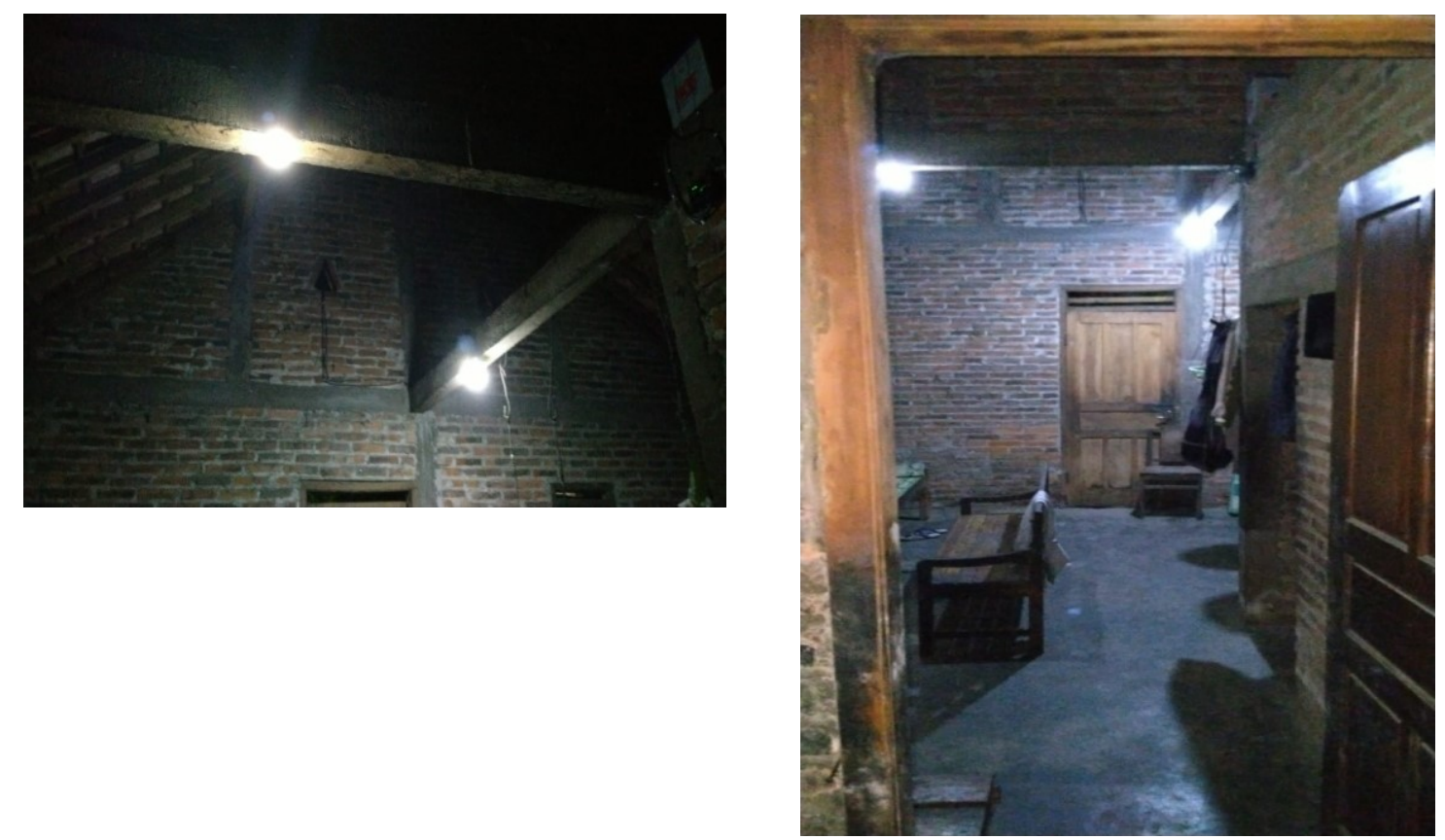

Gambar 5. Penerangan rumah warga dengan menggunakan panel surya

Dengan pemasangan satu buah panel surya, mampu menerangi sebuah rumah dengan 2 buah lampu ukuran 20 watt dan 2 buah lampu ukuran 10 watt. Hal ini sangat membantu warga yang belum teraliri arus listrik PLN. 


\section{KESIMPULAN DAN SARAN}

Kesimpulan

Kegiatan pengabdian kepada masyarakat ini berjalan dengan baik. Hal tersebut terlihat dari antusias warga dalam mendukung program pemasangan panel surya sebagai sumber penerangan. Walaupun belum dialiri listrik PLN, warga bisa menikmati penerangan skala rumah tangga dengan bantuan panel surya.

\section{Saran}

Pembelian paket panel surya bagi masyarakat cukup mahal diawal tetapi bisa diatasi dengan pembelian secara kolektif melalui koperasi desa dan pembayaran bisa dengan cara melakukan angsuran. Rekomendasi untuk kegiatan pengabdian masyarakat selanjutnya di lokasi ini perlu digali lebih dalam mengenai sumber daya alam yang ada pada lingkungan tersebut sesuai dengan kondisi alamnya.

\section{DAFTAR PUSTAKA}

[1] ----- Outlook Energi Indonesia. 2007. Dewan Energi Nasional. Jakarta.

[2] Suriadi \& Syukri, M. (2010). Perencanaan Pembangkit Listrik Tenaga Surya (PLTS) Terpadu menggunakan software PVSYST pada komplek perumahan di Banda Aceh. Jurnal Rekayasa Elektrika, 9(2), 77-80.

[3] Youness, S., Claywell, R., and Muneer, T., (2005). Quality Control of Solar Radiation Data: Present Status and Proposed New Approaches, Amsterdam, Journal of Energi, Volume 30, Issue 9, pp. 1533-1549

[4] Prabowo, Yani., Suwasti Broto, Gunawan P. Utama, Grace Gata dan Yuliazmi. 2020. Pengenalandan Penerapan Pembangkit Listrik Tenaga Surya di Desa Muara Kilis Kabupaten Tebo Jambi. Jurnal Pengabdian Masyarakat Universitas Merdeka Malang Vol.5(1) Maret 2020, 70-78

[5] Purwoto, B. H., Jatmiko, Alimul, M., \& Huda, I. F. (2017). Efisiensi penggunaan panel surya sebagai sumber energi alternatif. Emitor, 18(1), 10-42.

https://doi.org/10.23917/emitor.v18i01.6251

[6] Pangestuningtyas, D. L., Hermawan, H., \& Karnoto, K. (2014). Analisis pengaruh sudut kemiringan panel surya terhadap radiasi matahari yang diterima oleh panel surya tipe larik tetap. Transient: Jurnal Ilmiah Teknik Elektro, 2(4), 930-937.

https://doi.org/10.14710/transient.2.4.930-937 